\title{
UNESCO's Influence on Education of Youth and Adults in Brazil: $A$ Debate on the Relationship of Work and Education
}

\author{
Ada Augusta Celestino Bezerra ${ }^{1} \&$ Márcia Alves Carvalho Machado ${ }^{1}$ \\ ${ }^{1}$ Tiradentes University of Sergipe, Sergipe, Brazil \\ Correspondence: Ada Augusta Celestino Bezerra, Postdoctoral Senior Education, Master and PhD in Education, \\ Professor of the Graduate Program in Education, Tiradentes University of Sergipe, Sergipe, Brazil.
}

Received: February 21, 2017

Accepted: March 9, 2017

Online Published: May 26, 2017

doi:10.20849/aes.v2i2.154

URL: https://doi.org/10.20849/aes.v2i2.154

This article is part of the Master Degree Dissertation: "Politicas Educacionais no Brasil na Área de Educação de Jovens e Adultos: o Caso do Programa Brasil Alfabetizado em Sergipe", presented at Tiradentes University in Aracaju.

\begin{abstract}
This article discusses the qualifying function of the education of the young and adults (EJA) and work, as a humanizing source of wealth and welfare, which differs from the perspective of education throughout life. It is grounded on the critical sociological approach, being DELINEADO with a study of critical revision using documental and bibliographic researches and with a qualitative analysis of the information. It concludes that the educational policies in Brazil are markedly influenced by the determinations from UNESCO, responsible for the diffusion of the perspective of lifelong learning, subsumed to the requirements of the job market and to the social role that is meant for each individual and which differs from the qualifying function of EJA and work. As a political-pedagogical implication of this statement, it is noted that the worker-work relationship is socially determined and that EJA cannot ignore this reality, given that the knowledge of the mechanisms of exploration will make possible and clarify the human emancipation of the worker.
\end{abstract}

Keywords: lifelong learning, youth and adult education, qualifying function, job

\section{Introduction}

\subsection{The Qualifying Function of EJA: A Necessary Debate}

Among the challenges imposed to teaching, especially in the scope of higher education to the training agencies, there is a need of discussing the influences of the orientations from supranational organizations, e.g. UNESCO, where it comes to policies for education and culture. These orientations have been crystallized in the educational political agendas around the world. In general, they present a neoliberal nature, being little discussed by academic and school communities, institutions which have little participation in the decisions that directly influence their day-to-day activities and the future of many young people and adults.

We believe that any analysis to be done on educational policies in Brazil, e.g. the ones for the Education of the Young and Adults (EJA), object of our researches, must be preceded by the discussion of the comprehension of the bases in which have been developed, for more than three decades, the debates of the international organizations about the policies of human training around the world, focusing on concepts that are already consolidated in common sense, such as lifelong learning, as well the restrict comprehension of the relationship between work and education, which are interlaced and penetrate in the proclaimed qualifying function of the education of the young and adults.

These categories are pinched from the theoretical framework of the progressive thinking of education and are transformed by the neoliberal proposals and discourse, being emptied of their transforming content, of emancipatory character, to be treated in an abstract context of equity which distances itself from the equity and social justice deepened in Marxist political economics. Work stops being understood in its ontological dimension (linked to the humanizing dimension of Man and society) and with its property of generator of wealth and social welfare, to be reduced into a process of production subsumed to the global capitalist exploration, in its varied and sophisticated forms of international division of work and growing extraction of relative added value. The 
qualifying function of EJA, since the JUDGMENT CNE/CEB $n^{\circ} 11 / 2000$, homologated by the Minister of Education, in 07/06/2000, and published in the Diário Oficial da União, from 09/06/2000, Section 1e, p. 15, has focused on continued education and constant requalification of the worker, and cannot be reduced to the basic formation of the worker or his professionalization.

Socialist ideals, fights and victories are appropriated and simplified before the conditions of EJA and the experience of the working student, in the neoliberal perspective that tries to, according to UNESCO (2010a, p. 23), "a crucial role to fulfill, to guarantee the search for equity and social justice, along with the maintenance of democracy and human dignity." Since these principles are in the center of the future agenda for the education of adults, we understand it as a global direction where it comes to EJA, reason why it was incorporated in this modality in Brazil. However, we ask the question in which measure did the education of young people and adults in Brazil, by incorporating the role proposed by UNESCO for EJA, incorporate its qualifying function in the perspective of qualification of life, in which work is inserted?

The question is subtle and delicate and is also linked to the formation of EJA teachers, because it is directly associated to the teaching social function of developing in the young and adults this knowledge that learning is done throughout life, in the diverse social environments, and not only via formal education. Many initiatives in EJA are presented as a proposal for non-formal education, which are developed in side, or outside, the educational institutions, e.g. the Programa Brasil Alfabetizado (PBA) and Programa Nacional de Inclusão de Jovens (Projovem), the last one integrated to EJA the Professional Education, supposedly taking work as an educational principle. These are initiatives that focus on the formation of abilities for life, the job market, culture in general, independently of educational degrees and age categories, as is clarified by Atchoarena and Gasperini (2003). What is not explicit is that all of this strengthens the thesis of small government, leaving to the citizen the choices about this formation throughout life, releasing the public sphere of its responsibility to the continued formation of the worker.

It is not, in essence, the same qualifying function of the education of the young and adults proclaimed by the already cited Judgment, whose resolution CNE/CEB n ${ }^{\circ} 1 / 2000$, published in the Diário Oficial da União, from 19/07/2000, Section 1, p. 18, with the National Curricular Guidelines for the Education of the Young and Adults, had as a Relator Conselheiro the Prof. Dr. Carlos Roberto Jamil Cury. Here, the qualifying function relates education to work, therefore, valuing the propaedeutic and the polytechnic, which in current days is still not amply understood in its ontological dimension of valuing human work, but, above all, as a process that increases capitalist wealth. This way, in educational policies, the second understanding is still strongly kept, instead of the first, and, therefore, it is necessary to understand how the relationship between work and education was done in Brazil, as well as the orientations that this category has in the educational policies of EJA.

The update of knowledges throughout life would be the permanent function of EJA in the terms of the referred judgment, a qualifying function, not necessarily one of professionalization (Note 1). The meaning of the qualification for EJA is that of qualifying human life, of Man in his omnilaterality, in opposition to the successive compensatory policies, in order to break up with the assistentialist practices and to strengthen continuity links with formal education and social transformation, respecting diversity and establishing as principles the continued and emancipatory formation of young people and adults.

This article proposes, then, to discuss the qualifying function of the education of the Young and adults (EJA) and of work, as a humanizing source of wealth and welfare, which differs from the perspective of lifelong education. This discussion comes from researches developed in the Post-Graduate Program in Education of the Tiradentes University, Aracaju-Sergipe, with financial and material support from the Coordenação de Aperfeiçoamento de Pessoal de Nível Superior (CAPES) and by the Instituto Nacional de Estudos e Pesquisa Educacionais Anísio Teixeira (INEP), object of which were the educational policies for the young and adults in Brazil, and discusses the qualifying function of EJA and of work, under its aspects of humanization and creation of social welfare and wealth, which differ substantially from the perspective of UNESCO on lifelong education. The approach used was that of a critical sociology, which, according to Afonso (2001b), assumes an explicit political and ethical compromise, searching for and valuing the unstable and tense conflict between scientific practices and the inherent politicity in every human action, translating itself, above all, by explaining in an empirical and rigorous manner, the analyzed educational policies.

\section{Method}

The methodology was based on a documental research, with the analysis of documents from UNESCO, in particular the two main regulatory marks on lifelong learning, the Faure Report (1972) Learning to Be, and the Delors Report (1998) The Treasure Within, which articulate the fundamental principles of lifelong learning, and 
by the bibliographic survey that grounds the discussion about the categories - qualifying function of EJA and work. The treatment applied to the information was a qualitative one.

Theoretically, where it comes to the social function of school, we based our work on: the researches from Bourdieu and Passeron (1975) that indicate it as an institution that confirms and reproduces the cultural hierarchy, via familial cultural capital, originated in the social division of work; the studies of Baudelot and Estabet $(1976 ; 1979)$ which indicate that this social division of work is what determines the division of school networks; mainly, though, we took as an assumption the thesis of the social function of school according to Lautier and Tortajada (1978), which implicate its insertion in the context of social warfare, under penalty of becoming purely reproductive of hegemonic relations. This position reinforces the role of school in the superstructure, associated to the action of intellectuals in the organization of culture and sedimentation of counter-hegemonies, as is demonstrated by Gramsci (1991a; 1991b).

\section{Regulatory Marks of UNESCO: The Defense of Lifelong Learning}

For more than three decades the perspective of lifelong learning has been utilized in the promotion and implementation of adult education. Driven by the orientation of international organizations, especially UNESCO in 1976, when in its $19^{\circ}$ General Conference Session, it approved the Nairobi Recommendation for the Development of Adult Education and determined that governments would have the compromise of promoting adult education as a part of their educational systems, this perspective has been strengthened and consolidated by the public educational policies around the world. These two cited documents were the determining references for its promotion: the Faure Report ${ }^{2}$ (1972) Learning to Be, and the Delors Report (1998) The Treasure Within (UNESCO, 2010a).

As permanent education, the Faure Report, from 1972, states that " $[\ldots]$ education is no longer defined in relation to the content of assimilating, but, instead, is conceived as a process of the human being that, through the diversity of his experiences [...]" (UNESCO, 1973, p. 220). In this perspective,

La educación tiene fundamentos sólidos no sólo en la economía y la sociologia, sino en la evidencia aportada por la investigación psicológica de que el hombre es un ser inacabado y que sólo puede realizar-se al precio de un aprendizaje constante. Si esto es así, la educación tiene su sitio en todas las edades de la vida y en la multiplicidad de las situaciones y de las circunstancias de la existencia. Recobra su verdadera naturaleza, que es la de ser global y permanente, y franquea los límites de las instituciones, de los programas y de los métodos que le han sido impuestos en el curso de los siglos. (Note 2)

Standing out in the preamble of this document are the first impressions of education, posed as a problem of exceptional difficulty, but a task of universal importance especially for those who worry about improving the world, in an attempt to show that traditional systems of teaching need improvements and adaptations, in a time when youth was already opposed to the pedagogical models and the impositions from the institutions of learning.

The discourse about the scientific and technical revolution is also of note, as well as the one about democracy. In relation to the first aspect, it is asserted that it can be easily verified that progress of education followed economic progress, therefore leading to the assumption that the development of media would be a way for individuals to obtain political or economic power, especially as consumers and citizens. Where it comes to democracy, it is asserted that no nation is satisfied in this field and that the wish for a different democracy comes to light, aspect in which the formation of human personality would play a decisive role.

The qualitative change, the motivation, and the work, would be the third focus of the intentions. It stands out that, in this sense, it is confirmed that developing countries search for views on education that are similar to those of which are already developed. In developed countries, there is a dual characteristic of the systems, pre-technological teaching on one side, and elitism in hiring people with a high level of education on the other. This model becomes disadvantageous, since very often it is not adaptable to the cultural or social and human environments. The model represented, on one side, the passage from the pre-technological to the technological, and, on the other side, the creation of a very popular teaching from an educational system still restrict to only a minority of participants. It was verified by this Report that such a movement not always happened in developed countries, which believed to be creating mass education; it was restrained in the failures of access from the students of the masses to higher level education. Therefore, from the economic point of view, these countries were developed, while in education they presented an internal situation of underdevelopment.

The profile of the students, coming from the working class, with symptoms of maladjustment and failure, was analogous to those observed in countries colonized by a "superficial" western education; in both cases, it was verified that there were problems conjugated of motivation and job, which determined the entry and leaving from 
the cycle of formation, movement considered a determinant for the success of the individual. In other aspects, it rejected the tendency for neomalthusianism (Note 3), defending that the objective of education is to allow Man to be himself, <devernise>, according to the applied expression, in relation to work and economic progress; its purpose should not be only to prepare young people and adults for a specific profession, but to a life that allows for professional mobility and to permanently increase the wish for learning and formation. Hence the intention of seriously rethinking the objectives, modalities and structures of teaching.

The update and amplification given to the perspective of permanent education, constant in the Faure Report, by considering the alterations by the scientific progress and the new forms of economic and social activity, and that is inevitable to conciliate a general culture with the possibility of studying, in depth, few subjects (believing that general culture is the passport for a permanent education, since it provides both taste and bases for lifelong learning), clarifies that the new perspective of lifelong education "allows for sorting - and the same time valuing the different phases of learning, articulating transitions, and diversifying individual routes" (UNESCO, 2010b, p. 15). It is verified, from what has been exposed, that in this trajectory of orientations it seems to come to light a change of the paradigm in the education of adults, once that the focus stops being permanent education and becomes lifelong learning. What is seen more often is, in fact, the neoliberal mark emphasizing the same elements, without any gain for the subject of learning, in humanizing terms, of source of wealth and social welfare.

What also stands out in the document is a historical revision of education, that the mark for the creation of the universalization of education is associated to the Industrial Revolution, however, even almost four decades later, the Faure Report indicates that the right for education still has not been materialized. In the case of Latin America, the distribution of the percentage of students, considering enrollments, were higher in the basic level, $80 \%$, and in high school and higher level enrollments were of $17 \%$ and 3\%, respectively, while the average for developed countries were between 54 and $68 \%$. It was observed that more than half "[...] of the inhabitants, adults and children, had never gone to school, less than $30 \%$ of the young people go to high school, and less than $5 \%$ go to an institution of higher education" (FAURE et al, 1973, p.88). In this sense, universality constitutes one of the basic elements that confer the universal extension of all rights to the human person, being this last characteristic the only requirement for the ownership of rights, idea strengthened by the Declaration of Human Rights, since 1948.

The Delors Report recognizes that the recommendations of the Faure Report are still valid and suggests a rethinking and amplification of the permanent education in favor of the conception of lifelong learning. It was "the result of the works of the commission that, between 1993 and 1996, dedicated itself to tracing the guiding lines of world education in the XXI century [...]" (SAVIANI, 2008a, p. 433) meaning to bring to society and interest on lifelong education, considering it one of the keys of the keys to access to the 21 st century, which goes beyond the traditional distinction between initial education and permanent education (UNESCO, 2010c). (Note 4)

The report "was published in Brazil in 1998, with presentation from the then minister of Education, Paulo Renato Costa Souza, in which he highlights the importance of this document for the task to which MEC was meant for, of rethinking Brazilian education" (SAVIANI, 2008a, p. 433). The commission was coordinated by the then president of UNESCO, Jacques Delors. The document brings in its preface the understanding of the coordinator on the difficulties of the time (the 1990 decade), faced by leaders, in relation to what he named a "globalization" of international relations.

[...] imposta pela abertura das fronteiras econômicas e financeiras, impelida por teorias de livre comércio, reforçada pelo desmembramento do bloco soviético, instrumentalizada pelas novas tecnologias da informação a interdependência planetária não cessa de aumentar, no plano econômico, científico, cultural e político (UNESCO, 1998, p. 35). (Note 5)

Of notice is the clear linking done of education with economic processes, since the first chapter, where there is an explanation on the world society and the changes due to globalization, as well as the favorable and unfavorable aspects of these changes for already developed countries and those in the process of development. In this sense, including on the characteristic that globalization has of "constituting scientific and technological networks that are interconnected, the research centers and big companies of the whole world" (UNESCO, 1998, p. 39) which tended to worsen disparities, manifesting itself in problems that directly affected educational systems, such as in the case of international migrations. Although the report foments, among other aspects, the mutual comprehension oin the "sense of responsibility and more solidarity, in the acceptance of our spiritual and cultural differences [...]" (UNESCO, 1998, p. 50), democratic participation, and human development, it also defends education in the perspective of its effects on economic growth and defines it as a "vehicle for cultures and values, as the creation of a space for socialization, and as the crucible of preparation of a common project" (UNESCO, 1998, p. 51). Such definition is similar to the then current thinking in Brazil in the educational reforms of 1930, when there was also a 
defense of a common project in which nationalism was reinforced. However, the ideal now reinforced is one from neoliberalism, dressed under the mantle of the "requirement of a society of global scale". In this sense, a new political project is verified, to create an individual identity, which, though defending the respect towards the origins of the individual, is marked in a common world scale, which again levels or unifies individuals and creates an equity, similar to the ample understanding of Afonso (2001a), as being one of the expected products of the legitimate appliance of symbolic violence (in the understanding of Pierre Bourdieu), i.e., it is seen as the result of cultural and identity imposition from the dominant class to the dominated class and which also represents a cultural and identity imposition to adequate it to the needs of this new globalized society that imposes itself.

The report brings implicitly in its discourse the neoliberal defense, by suggesting that "the educational options must be made in the sense of a greater responsibility of each citizen, preserving the fundamental principle of equality of opportunity", but how would that be possible if there is no economic equity among people? Hence, such measures are left under the auspices of policies, the understanding of which is that of a decentralization which associates the different social actors to the processes of decision, understanding that this action does not need a regulation of the group, but "diversifies financing, grounded under the logic of partnerships" (UNESCO, 1998, p. 193). Even if the document does not entertain changes of curriculums or contents, in relation to this exposed social dimension, viewing lifelong education, it supposes that:

[...] a implementação de uma escola básica de caráter universal, de boa qualidade e acessível a todos, seja qual for a sua situação geográfica, material, social ou cultural. Oferece a todos a possibilidade de dispor de novas oportunidades, terminado o ciclo de educação inicial. Passa também pelo estímulo aos diversos talentos, pela criação de múltiplas carreiras e deve mobilizar, para este efeito, o conjunto de recursos acumulados pela sociedade. (UNESCO, 1998, p. 193). (Note 6)

The report also defends the use of educational synergies, the sense of valuing the relations of complementarity that are created in different educational environments. It considers a need of exploring the possible synergies between the knowledge and the knowledge of making, or between both the knowing how to live and knowing how to be, believing that " $[\ldots]$ the educational offer, by expanding itself outwards of the formal system, gives an answer to the search for diversity manifested by all societies, and entices varied educational routes" (UNESCO, 1998, p. 116), strengthening and making believable the neoliberal perspective in favor of decentralization of education, that there must be a dynamic, translated in partnerships, between the educational institution or university and the different "educational" alternatives, as well as a process of transformation and questioning of traditional educational practices. Although the discourse is about deliberate integration of the informal, where it comes to formal education, there is a defense of informal education.

A Comissão é, pois, favorável a uma ampla descentralização dos sistemas educativos, apoiada na autonomia das escolas e na participação efetiva dos agentes locais. Pensa que esta tendência é reforçada pela necessidade de uma educação que se estenda ao longo de toda a vida, assim como pela emergência de sociedades educativas voltadas para os recursos da educação informal (UNESCO, 1998, p. 173). (Note 7)

In this aspect, the sense given by Atchoarena and Gasperini (2003, p. 21) to informal learning should be explicit: "form of learning that isn't structured or organized by any institution; it occurs via daily interactions with the context that offers new information and knowledge, e.g., through conversation, reading, radio or television".

[...] é reforçada pela necessidade de uma educação que se estenda ao longo de toda a vida, assim como pela emergência de sociedades educativas voltadas para os recursos da educação informal. Está, contudo, consciente de que as formas de organização e de gestão da educação não são fins em si mesmas, mas instrumentos cujo valor e eficácia dependem muito do contexto político, econômico, social e cultural. As medidas de descentralização podem ser levadas a cabo tanto através de processos democráticos, como de processos arbitrários e geradores de exclusões sociais (UNESCO, 1998, p. 173). (Note 8)

Besides the aforementioned reports, UNESCO promoted, in various moments, a bigger debate on what it has been calling a new paradigm. In 1997, the fifth International Conference of Adult Education (CONFITEA V), made in Hamburg, Germany, discussed, among its themes, lifelong learning and conferred the importance of non-formal programs for adult education.

From the introductory discourse done by the General Director of UNESCO of the time, Federico Mayor Zaragoza, in the Declaration of Hamburg, final document from the CONFITEA V, a partnership is consolidated between non-governmental institutions, in the sense that the governments of member countries should work in close collaboration, the education and formation with civil society (ONGs, employers, unions or other social entities). This orientation is on par with the concepts from Afonso (2001b), in which partnerships are constituted, currently, in a fundamental axis in elaboration and implementation of public and educational policies, meaning a reupdate of 
the State's power of regulation, contributing to the replacement of the notion of government by the notion of "governing".

Also linked to the discourse of UNESCO is the idea that in order to beat economic crisis, all countries should take measures for its citizens, whatever their professional status are, to perfect, continuously, their knowledge and competences, which would allow for their participation in the effort for growing productivity, and for this there was the need for a continuity in the State in the action of successive governments (UNESCO, 1999). In this sense, it is possible to comprehend why there were few changes in the social projects applied by Fernando Henrique Cardoso (FHC), Luiz Inácio Lula da Silva and Dilma Rousseff, once that the character of continuity has been one of the recommendations of the international organizations, such as the example exposed from UNESCO where it comes to education. The Declaration also emphasizes the transformations suffered by the education of adults and their amplification not only for their necessity and that of education, but also for continuing in the society of knowledge, stating that in the center of these transformations is the new role of the State. It considers the latter as the main agent for assuring the right for education for all, and affirms that there is a need for expanding partnerships with civil societies, aiming for education. The role that the State must play, in the recommendations from UNESCO, is that of a provider, consultant and financing agent that must monitor and evaluate at the same time.

In a more emphatic manner, in 2009, UNESCO's discussions continued around education and lifelong learning. During the preparation for the CONFITEA VI, made in Brazil, in Belém, Pará, the Preparatory National Document for this Conference was considered a result from the beneficial debate over this subject and had the intent of contributing for the advancement of proposals and implementation of public state policies for EJA in the country. Hence it was said that:

[...] a aprendizagem ao longo da vida constitui "uma filosofia, um marco conceitual e um princípio organizador de todas as formas de educação, baseada em valores inclusivos, emancipatórios, humanistas e democráticos, sendo abrangente e parte integrante da visão de uma sociedade do conhecimento". Destacou a sua compreensão da natureza Inter setorial e integrada da educação e aprendizagem de jovens e adultos, a relevância social dos processos formais, não formais e informais e a sua contribuição fundamental para $o$ futuro sustentável do planeta. (UNESCO, 2010b, p. 4) (Note 9)

Throughout the Conference, there was the approval of the Mark of Action of Belém, in which there is a consolidation of the role of lifelong learning, seen as fundamental in the solving of global issues and educational challenges.

This mark reinforces and supports the definition of adult education established in the Recommendation on the Development of Education for Adults, adopted in Nairobi (1976) and deepened in the Declaration of Hamburg (1997), with the understanding that:

[...] a educação de adultos engloba todo processo de aprendizagem, formal ou informal, em que pessoas consideradas adultas pela sociedade desenvolvem suas capacidades, enriquecem seu conhecimento e aperfeiçoam suas qualificações técnicas e profissionais, ou as redirecionam, para atender suas necessidades e as de sua sociedade (UNESCO, 2010b, p.5). (Note 10)

In the scope of policies and legislative measures, the recommendation is that these, in relation to the education of adults, need "to be embracing, inclusive and integrated, in the perspective of "lifelong learning, with basis in sectorial and inter-sectorial approaches, embracing and articulating all components of learning and education" (UNESCO, 2010b, p.9)". It is in the qualitative aspect that the recommendations from the Mark of Action of Belém (2010c) point to the improvement of teacher formation. In this sense, the quality in learning and education of adults is understood as "[...] a concept and a holistic, multidimensional practice, which requires constant attention and continuous development" (UNESCO, 2010b, p.12) and promotion of a culture of quality requires:

[...] conteúdos e meios de implementação relevantes, avaliação de necessidades centrada no educando, aquisição de múltiplas competências e conhecimentos, profissionalização dos educadores, enriquecimento dos ambientes de aprendizagem e empoderamento de indivíduos e comunidades (UNESCO, 2010b, p.9). (Note 11)

Hence, the compromise that should be taken by member countries, where it comes to the educators of adults, would be to improve their formation, capacitation, conditions of work and professionalization, indicating as a means for this objective the establishment of partnerships with institutions of higher learning, associations of teachers and civilian organizations, in a clear assertion of the neoliberal ideals that defend partnerships and the outsourcing of essential services provided by the State. 
Even though the aforementioned discourse takes quality into consideration, including on the formation of educators of adults, its totality, as well as its various dimensions, and alerts to the requirement of attention and continuous following, the indication of establishing partnerships with the civilian society, characteristic already exposed as relative to the neoliberal model that has been followed by Brazil, might indicate a reduced action of the State, in the sense of subsidizing and delegating its actions, and also seems to indicate an easy way for (de) responsibility of the government towards the formation of teachers.

In relation to the orientations from international organizations, the documents from UNESCO, already cited in the beginning of this session, contributed in a notorious way, globally, to driving agendas and educational political proposals that incorporate the qualifying function of work in education. Hence, the Faure Report, in the decade of 1970, in relation to work, understood the school as a decisive factor for this preparation:

Sin embargo, tanto en el presente como en el porvenir, la escuela, es decir, todo organismo concebido para dispensar una enseñanza metódica a la generación que comienza su vida, es y será el factor decisivo para la formación de un hombre apto para contribuir al desarrollo de la sociedad, para tomar una parte activa en la vida, es decir, válidamente preparado para el trabajo (UNESCO, 1972, p. 39). (Note 12)

In this sense, one of the recommendations of the document, in terms of innovations and searching for alternatives for education, would be to innovate in the reforms. One of these recommendations for innovation being that of presenting proposals to abolish the rigid distinctions between the different types of professional, technical, scientific and general teaching, in a way that would be conferred to education, since the primary and secondary teaching, simultaneously to the manual, practical, technological and theoretical dimensions. Demonstrating, thus, the will that all these dimensions are developed in the student. It is recommended to develop in secondary school (expression used then), through school of professional or technical formation, elucidating, in this sense, the understanding that education has a very important role towards professional formation and the economy, also attributing, in the discourse, an educational role to companies. However, this responsibility of the companies, to provide education in a collaborative manner, was related to the complementary formation for the industry, especially for the young coming from technical schools.

In a clear favoring of non-formal processes of education, the document proposes the promotion, after secondary school, of a great diversity of new educational structures that are not limited to universities and in which the conditions for admission were liberal and non-formalistic, but mainly centered in the future professionals. That way, it suggest the creation of "excellences centers", so that developing countries wouldn't follow the same models of post-secondary teaching used in developed countries and could create their own.

With relation to the education of adults, the document affirms that in the next ten years the objective is literacy, and, in this sense, the effort should be both from the public and the private spheres, in a clear defense of the public $\mathrm{x}$ private partnerships, characteristics present in the neoliberal model. All the efforts should be implemented, in a tridimensional action that would count with the utilization of all schools, the creation of special institutions for the education of adults, or differentiated extracurricular activities, and guaranteeing the favorable conditions for the organization of educational activities - collective of individual - as well as the promotion of self-education, among others.

Esta acción tridimensional no podría concebirse sin las aportaciones financieras y técnicas de los poderes públicos y del sector económico (industrial y agrícola). Pero una gran parte de los esfuerzos a realizar en este dominio corresponde a la iniciativa de los grupos, asociaciones e individuos. Esta función de la iniciativa privada constituye una garantía esencial del respeto a las libertades y pluralidades y favorece la innovación pedagógica. (UNESCO, 1972, p. 291). (Note 13)

The Faure report also emphasized the need of attributing an important place to literacy in all programs relative to the adult population in countries where there was high rates of illiteracy, under the form of mass literacy measures, articulated to the objective of developing the country, being the effort proportional to that of the strategies of socioeconomic development.

In the 1990 decade, the Delors Report also influenced educational policies for the XXI century in the world where it came to the education $\mathrm{x}$ work relationship. The document suggests a rethinking of the place occupied by work before society, because, to create it, "human imagination must be capable of being ahead of technological advancements" (UNESCO, 1998, p. 18), if it wants to avoid worsening problems such as unemployment, social exclusion or development inequalities. The report recognizes that the search for education for economic reasons hadn't stopped growing globally and that the relationship between the rhythm of technical progress and the quality of human intervention is each time more evident, "as well as the need of forming economic agents able to utilize new technologies and that show innovative behavior" (UNESCO, 1998, p. 71). Therefore, it establishes a need of 
creating new aptitudes, and affirms that educational systems must give answers to them, in ways that assure schooling or professional formation in the search for a working force of high technical level. And where it comes to the permanent formation of workforce, it declares that it:

[...] adquire, então, a dimensão de um investimento estratégico que implica a mobilização de vários tipos de atores: além dos sistemas educativos, formadores privados, empregadores e representantes dos trabalhadores estão convocados de modo especial. Observa-se, assim, em muitos países industrializados um aumento sensível dos meios financeiros dedicados à formação permanente. Tudo leva a pensar que esta tendência aumentará devido à evolução do trabalho nas sociedades modernas. [...] Já não é possível pedir aos sistemas educativos que formem mão-de-obra para empregos industriais estáveis. Trata-se, antes, de formar para a inovação pessoas capazes de evoluir, de se adaptar a um mundo em rápida mudança e capazes de dominar essas transformações. (UNESCO, 1998, p. 71-72). (Note 14)

This is, without a doubt, a discourse favorable to the education turned to the needs of the job market, which is greatly contrary to the defense of human development and the possibility for the individual to take positive and freeing steps, which would be possible with an awareness of his identity and, paradoxically, defended by the report as being a responsibility of education.

For education to fulfill all of its missions, the Commission of this report advised that it was organized around four fundamental learnings, which, throughout life, would be pillars of knowledge: learning to know, learning to make, learning to live together and learning to be. Work, understood as professional formation, should be closely related to learning to make, in a way that the student could be taught to put his knowledge into practice and adapt education to future work. From the discussions there started to exist a defense of the idea that, for work in the industry sector, the notion of personal competence, instead of professional qualification, as a consequence of the technical progress that modified the required qualifications (replacement of physical tasks by intellectual tasks), in a clear propensity to stimulate the enhancement of the cognitive domain, not through the liberating and transforming education of Man, but through favoring work, which is dematerialized by the innovation of the new systems of production. Such idea was also applied to the commercial and service sectors, in which activities of communication and information became primordial. Hence are suggested, among recommendations:

Aprender a fazer, a fim de adquirir, não somente uma qualificação profissional, mas, de uma maneira mais ampla, competências que tornem a pessoa apta a enfrentar numerosas situações e a trabalhar em equipe. Mas também aprender a fazer, no âmbito das diversas experiências sociais ou de trabalho que se oferecem aos jovens e adolescentes, quer espontaneamente, fruto do contexto local ou nacional, quer formalmente, graças ao desenvolvimento do ensino alternado com o trabalho. (UNESCO, p. 101-102). (Note 15)

It is consolidated then, through UNESCO's recommendations in this document, the qualifying function of education, understood as professional qualification, and amplified by the insertion of competences, also turned to the job market, especially for working with the new technologies that the various economic sectors came to need. It is established, also, around the perspective of lifelong learning, a need that this is a necessary adaptation to the requirements of the job market, and a condition for a more effective control of the rhythms of the human person (learning for work and citizenship). It is understood that it must make the human person "[...] have awareness of itself and the environment that involves her, and to fulfill the social role that is meant for her in the job market and the community." (UNESCO, 1998, p. 107). The document suggests that the more schooling of young people, progress in literacy and new impulse of basic education happen, the more will be a search for the education of adults; the sociologist professor Paul Bélanger (1994) affirms that this education:

[...] reveste-se de variadas formas: formação básica num quadro educativo não formal, inscrição a tempo parcial em estabelecimentos universitários, cursos de línguas, formação profissional e reciclagem, formação no seio de diferentes associações ou sindicatos, sistemas de aprendizagem aberta e de formação a distância (UNESCO, 1998, p. 108). (Note 16)

This understanding refers directly to the characterization of the aforementioned program from the Federal Government, the Programa Brasil Alfabetizado (PBA), as a policy for the literacy of the young and adults, non-formal, and, in the creation of this education, non-formal education is not opposite to its formal counterpart, but mutually fertilized.

\section{The Work-Education Relationship as Key to the Proclaimed Qualifying Function of Education}

Work was and still is in this century, regardless of its qualities, or, as is proposed by Offe (1989) (Note 17), regardless of the loss of its centrality, an economically and socially important category in Brazil, in a way that makes it still be considered, by many academics of education and political economics, in its formulation, as an 
educational principle, as being a typically human and humanizing activity for Man himself and society. Its relationship with education is bilateral and intercomplementary. Although both categories present ample social practices, each one keeps its own specificities where it comes to the process of human training and the production of existence.

The ontological conception of work is distinguished in Marx (1982) in which there is a visible positivity of work for society and the individual, which prevails in the capitalist conditions of work. The ontological conception reaches work as a generic process understood as an activity of human self-creation, therefore, a historical act of the man that founds the building of knowledge, the ontological and historical dimension of the production of usage values being, as clarified by Bezerra (2007), a generator of wealth and social welfare.

Beyond these characteristics, which reveal its productive and useful facets which are manifested in the production of usage values, other elements of work are stressed by Marx (1982), like the mediation between men and between men and the external nature; typically a human activity, which transforms Man and Nature (social and natural orders); practical/theoretical unity; expression of culture and reproduction of existence; besides being a social practice that founds knowledge, therefore, having an educational character.

Through work, Man objectifies his intentions, transcends the natural dimension, under the mark of historicity, and advances towards emancipation, to the control of his freedom, differentiating himself from animals limited to their natural needs. The will of the worker is an important component to his performance, and presents itself the more subordinate and the less attractive are the contents and methods of working, and the less probability there is that he will make use of his own physical and spiritual capacities.

Entendido o trabalho no sentido mais amplo, o trabalho como produção da própria existência humana; o trabalho como possibilidade de transformação da realidade natural e social; o trabalho como dimensão fundamental da vida humana; o trabalho como cultura, como atividade reflexiva; o trabalho como fundamento do processo de elaboração do conhecimento; o trabalho como contradição, porque é uma realidade em que se apresentam pelo menos duas grandes contradições: entre homem e natureza e entre os homens, principalmente pelo fato de vivermos numa sociedade em que se processam várias formas de subordinação humana na realidade do trabalho. Enfim, essa noção mais ampla do sentido do trabalho é que nos inquieta numa realidade cheia de contradições como a nossa. (MACHADO, 1991, p. 53-54). (Note 18)

This worry is also about the concerns with the trends of education that have been implemented in Brazil, starting in the XX century, which came to follow the recommendations in the sense of incorporating since basic education the dimensions suggested by theory, technology, practice and knowledge, aiming for new aptitudes for professional training and the creation of a technical working force that maintains the economic environment and the capitalist system in the country. There is a need to consider all production about the work-education relationship, in a way that emphasizes the founding aspects of production, directly related to the practice of the productive worker, understood as the salaried worker that executes the process of work and produces added value in a direct way.

It's imposed, in this context, that there is mentioning of the division of work. Marx (1982) reports to the social division of work (characteristic form in all societies, a mark of human work, a phenomenon of task distribution, crafts or production specialties) which is distinguished from the manufacturing division (or technical division of work), marked by the division of the processes applied in the creation of the product, in numerous operations executed by different workers. The manufacturing division of work presents itself as the oldest and most innovative principle of the capitalist method of production, remaining as the basic principle of industrial organization. In the current stage of technological and scientific development, and with globalization, there is a new form of international division of work.

Two important aspects of this subject were formulated by Marx (1982): formal and real subsumption of the worker in capital. The direct producer, which was transformed by capital into a worker, remained, in a first stage, performing his craft, as he did before, in that situation in which the objective conditions of work belonged to himself.

In his relation to the object of work, there was also the keeping of the mediation of the same instruments. However, something fundamental changes, since the product that he makes no longer belongs to him, but to the capitalist, the proprietary of the means of production. This is the formal subsumption of the worker to the capital, in a manner in which it is already executed under the control of others; the working hours of the worker is controlled by someone else. 
O processo de trabalho converte-se no instrumento do processo de valorização, do processo da autovalorização do capital: da criação de mais-valia. O processo de trabalho subsume-se no capital (é o processo do próprio capital), e o capitalista entra nele como dirigente, guia; para este é ao mesmo tempo, de maneira direta, um processo de exploração do trabalho alheio. É isto o que denomino subsunção formal do trabalho no capital. (MARX, 1975, p. 73). (Note 19)

It is in this manner that work is formally subordinate to capital, subsumption that is given to the basis of the preexisting labor processes and by exploration of absolute added value. Therefore, in a way the worker is already divided, since he is alienated from his own work. It is about the alienation of the worker towards his own human work: he is separated, by capitalist appropriation, from the product of his work, which, although tacitly established, is a profoundly unequal relationship between people, based on coercion, continuously generating social conflict. "In the same way that we can consider the production of added value as a material expression of the formal subsumption of work to capital, the production of relative added value can also be seen as the real subsumption of work to capital". (MARX, 1975, p. 79).

Consequently, work in the capitalist society is an unequal relationship between men, and in it are embodied the plight of workers, in its individual or collective forms of revolt and resistance centered basically in the reduction of working hours, as well as, contradictorily, on the side of the capitalist, the continuous search for the reduction of working hours incorporated in the working force, aiming for the effective amplification of the time spent during these hours. This gap that the capitalist tries to increase, in time of spent and incorporated work (non-paid), deepens inequalities in this process of exchange of working hours: the one incorporated in the working force or working time socially necessary to its reproduction as merchandise (translated in the form of salary) and on work that grows in relation to the work necessary to the production of goods and services. It is the job of theory, then, also via school education, to uncover the hidden content of the appearances of manifested forms, although they are not dissolved by this, since they are peculiar to the bourgeois society, the result of relations that are structured differently according to the historical moment and under specific conditions, from which is deduced that work in its capitalist form can be taken as a target of criticism in the public school, the curriculum of which has work as an educational principle.

Although the discourse of UNESCO values work, it does so with educational policies which try to, through solid curriculum, mitigate the social, edifying and humanizing dimensions of work, emphasizing pragmatic aspect of the enhancement of the quality of life of the individuals that surpass the assurance of the simple maintenance of subsistence. This conception favors only the capitalist, to which the workers represent only working force that in the current social relations are reified. In this context, there is a need of underlining the importance of the teacher's mediation. The role of the teacher in formal education is fundamental, as a directed and systematic process, since only its practice, in the teacher-student relationship, can make feasible the ideal of, from the conditions of the concrete student, leading him to a more elevated comprehension of reality. Saviani (1987) situates education, and particularly the action of the teacher, in the scope of hegemony and persuasion. In this way, he criticizes the postures of spontaneity, populism instead of directivism, which removes from the educational practice its sense of labor, in the direction of a systematic creation of knowledge.

Therefore, in the context of the Marxist perspective, when talking about qualification of work or the worker, there is always a continuous recognition of the search for the theoretical-practical unity, for the manual work-intellectual work, including as one of the main functions of education. This way, there has been built in Brazil an ascendant trajectory, not only in educational policies, but even via Constitutions of the country, indicating the direct relationship that it tried to maintain between education and economic development.

In the educational policies we can verify, through laws and bases of education, a progressive search in the sense of the relationship between work and education with constitutional principles. In the beginning of the 1960 decade, with the law number 4.024/1961, first LDB, the courses of the same levels of teaching started to have complete equivalence, which legally equated professional teaching to academic teaching. The LDB/1961 organized high school, intended for the formation of the teenager, in higher proportion, on courses turned to the professional formation, only the secondary course did not graduate professionals, while the technical and those of education of teachers for primary and pre-primary education were driven by this objective. A dualism was consolidated: propaedeutic education and professional education.

With the Law number 5.540, from 1968, there was a fixation of the norms with which higher education and its articulation with middle school would work and be organized, and after, with Law number 5.692, from 1971, there was the fixation of the bases and guidelines for the teaching of elementary and high school, and organization of supplementary teaching. The referred law, in group with other legislation, created compulsory 
professionalization, as a strategy of the government towards restraining middle class demand for higher education which contributed to an even higher de-characterization of high school, divided between professional teaching and its propaedeutic counterpart. With LDB/1971 the option of the State for a professionalizing education was evident, in opposition to a formation that aimed for the continuity of studies in higher education.

The professional preparation could be started in the elementary school, obligatory for children between the ages of 7 and 14. The article 4 of the LDB/1971 established that the curriculums for elementary and high schools would have a common nucleus, obligatory in the national scope, and a diversified sector, aiming to attend to the local peculiarities, to the plans of the institutions, and to the individual differences of each student. Article 5 defined that these disciplines would compose the full curriculum that would be partly of general education and partly of special formation, the latter having as its objective the probing of aptitudes and the initiation for work, in elementary school, and professional habilitation, in high school; and would be fixated when aiming for professional initiation and habilitation, in accordance to the needs of the local or regional job market. For Cordão (2005, p. 49), LDB/1971 "[...] universalized professional education in the high school level". With it, there is the crystallization of the dualism in the work-education relationship, explicitly incorporating the compulsory function of professionalization as the main objective of elementary and high school teaching, defining that these must "provide the student with the formation necessary to the development of his potentialities as an element of self-fulfillment, as qualification for work and preparation for the conscious exercise of citizenship" (BRASIL, 1971).

In 1982, by law number 7.044, the term "qualification" was replaced with preparation, and this preparation became obligatory, being an element of integral formation of the student, and should be a part of the curriculums of elementary and high schools. Article 76 established that, through preparation for work, the elementary school could qualify a professional in the level of the grade actually reached, and in high school there could be the professional habilitation, at the criteria of the institution of teaching.

Saviani (2008b, p. 39) affirms that the organization of the elementary school was centered on work in an implicit and indirect relationship and that, "[...] in high school, the relationship between education and work, and between knowledge and the practical activity, should be treated in an explicit and direct manner [...]". As a stimulus, for unionized work and its dependents, scholarships could be conceded by the federal government. These scholarships were part of the Programa Especial de Bolsas de Estudo (PEBE), instituted by the Decree number 57.870, from February $25^{\text {th }}$ of 1966 , and were aimed for the assurance of high school for poor students.

With LDB 9.394/1996 there was a keeping of the link between work and education, by considering that this link, beyond involving the formative processes of work, must be linked to the world of work and social practice. The law brings back to education one of its principles, the binding of school education, work, and social practices. In this sense, from basic education, means of progressing in work should be provided to the student, in a way that the contents of this level of teaching contemplate among its guidelines the orientation for him, and the adequation to its nature in the rural areas, in an explicit concern with work that was also done outside of the urban environment. During its processing, we remind that one of its alternatives came to assume the proposal of polytechnic teaching (from the then congressman Jorge Hage, of the Bahian PMDB, under the guidance of Prof. Dr. Lucília Regina Machado, of PCdoB).

The truth is that the project of this law came from Dermeval Saviani, linked to Anped (Associação Nacional de Pós-Graduação), attending to the new constitutional requirements and the progressive spirit of the time; to go through the National Congress, the congressman Otávio Elísio (RS) was appealed to, who presented it as a Project of Law in the Chamber of Deputies. The conceptual care of the project was clear, as well as the compromise to the public school, the effort for the building of the Brazilian educational system, the coherence of the guidelines and the bases of education proposed with historical-critical philosophy.

The amendments to the project in the Chamber of Deputies, coming from the representatives of the population, not always faithful to their bases and social movements, were many in the occasion: more than 4.000, as analyzed by Bezerra (2006). The project was defaced of its philosophical and progressive facets, in the conflict between conservative and progressive forces. The rapporteur of the alternative, congressman Jorge Hage (PMDB/BA), made possible a jump in quality before the adopted methodology: he travelled throughout the country, to Universities and Education Secretariats, and listened to educators, especially his advisor for this end: Prof. Dr. Lucília Regina de Souza Machado, biggest exponent in the discussion of polytechnics, in the reflection on work, its new qualities, its relationship with education and technology.

In this alternative project, the guidelines and bases for national education were centered on work as an educational principle. This was the axis defended to the Brazilian educational system. Biggest moment of the 
dream for a new LDB! After ample diffusion of this new text, the Education Commission, congressman Jorge Hage was already reporting the difficulties of reaching a consensus and the sacrifices made to assure that the essentials would be achieved. In the plenary of the Chamber of Deputies there were graver hardships: the rapporteur had to cede even more, trying to save the axis of the guidelines and bases for national education. Regardless of popular pressure, many were the losses. We shared, with other educators, moments of tearing. In the Senate there were at least three more new projects independent of the Guidelines and Bases for National Education that we had been building and negotiating. In this scope, the hegemonic project was that of Senator Darcy Ribeiro, which did not consider this trajectory. The result was a true patchwork which, transformed into law, is, has, to this day, suffered many criticisms and alterations, due to its contradictions, lack of unity and rupture in the work-education relation (BEZERRA 2006).

With relation to EJA, the conception of the function of qualifier, in the grounds of the aforementioned Judgment number 11/2000, which is about the National Curricular Guidelines for this modality, has as its discourse:

$\mathrm{Na}$ base da expressão potencial humano sempre esteve o poder se qualificar, se requalificar e descobrir novos campos de atuação como realização de si. Uma oportunidade pode ser a abertura para a emergência de um artista, de um intelectual ou da descoberta de uma vocação pessoal. A realização da pessoa não é um universo fechado e acabado. A função qualificadora, quando ativada, pode ser o caminho destas descobertas (BRASIL, 2000, p. 11). (Note 20)

The document also holds that this qualification is also necessary for those young people who are underemployed, unemployed, or have not yet been employed. The perspective here is that of polytechnics, however, some care is needed before this discourse, so that it isn't incorporated in a similar perspective, ideologically, to that employed by the Theory of Human Capital, which discusses multifunctionality and flexibility, and is greatly favorable to the promotion of economic development (educational functional to the capitalist system).

Way beyond the requirements of the domain of reading and writing skills go the new demands of the contemporary world for the full exercise of citizenship, with the emerging productive paradigm of the flexible accumulation that is developed in the current stage of science and technology. In this environment, there is a prevalence, in business circles and civil institutions in general, of different understandings of technical and social progress, challenging, and at the same time making education possible, particularly in public schools, in the sense of integrating every citizen in a historical project that favors the worker, his children and their formation. With the revolution in microelectronics (including computing and telecommunications), in microbiology (biotechnology), and the energy field (with nuclear energy), a new technical basis of work was developed, with repercussions in the technical and international divisions of work. We live the era of economic globalization, of urbanization, with crystallization of the rich-poor polarization, including in the macrostructural scope. The requirements of oral, written and visual communication are imposed to every citizen " $[\ldots]$ in a way that he demonstrates mobility, flexibility and adaptation to changes. Such skills are considered important so that the worker has the necessary conditions for trainability, and knows how to continue learning autonomously" (MACHADO, 1994, p. 183-184).

During the government of Fernando Henrique Cardoso, with its proposal of reforming technical and high school, there was a strengthening of the dichotomy of academic or propaedeutic education dichotomy and professional education or education for work, interrupting initiatives from some federal technical schools that were already trying to put work as the educational principle in basic education. In the beginning of the government of Luiz Inácio Lula d Silva, with Cristovam Buarque as Minister of Education, there was an attempt of correcting this rupture, with the advice of Prof. Dr. Lucília Regina Machado de Souza, with the proposal of Integrated High School, which, with the fall of the minister, was changed and to this day does not go beyond sparse experiences under the criteria of the states and IFS.

We conceive the current stage of the education of the young and adults between us as the result of social misery and exclusion, more than the cited process of development, as many affirm, which, in fact, require continued education of subjects. The institutionalization of EJA in the sense of supplying opportunities not given in younger ages, comes also from the deficiency of the regular public school system, beyond the objective conditions of the life of the population. Therefore, the excluded people from the formal system of teaching are so due to the precarious conditions of life, the lack of access to school or the access to bad schools, which expelled them. Today, this population faces the need of fully fulfilling their schooling, already in the condition of teenagers and adults, to survive in this contemporary society where there is a growing importance of knowledge.

We understand that the Education of the Young and Adults must, more and more, turn to the characteristics of the working student, therefore it should acquire shapes different from those of regular and children's schools, 
searching for a new model of school, structurally dedicated to attending the needs of the worker that returns to school to instrumentalize himself in the fight against unemployment and marginalization, constant threats in their lives. It is not about compensatory education, either in the sense of being dedicated to the poorest (supplying schooling for those who did not have it in the adequate age) or in the perspective that is reduced to the compensation of the lack of political awareness, characterized as essentially political (and even political-partisan), in detriment of the very content of science to be socialized with the young and adults.

The adult student has this interest and a notable knowledge over written language, being necessary that the teacher does not deny this previous knowledge, but that he works as a mediating-problematizing force between real and potential knowledge, opening room for this student to establish relations, participate as active subject of the construction of this knowledge, since for him, writing is an object that only the school can give him and that he can only have access to the information of others.

What we have seen in the current educational policies in this area are programs that mistake formal education for non-formal education, and that in the scope of the education of young people and adults itself there has been introduced a parallelism of programs that keep the formal propaedeutic system and points to the insertion of work as an educational principle in diverse classes, including with scholarships, but without the idea of continuity.

In this effort of comprehension of the current problems of educating the young and adults, there is a wide consideration that allows us to include from the literacy of young people and adults to the professionalization and the university. Only in this perspective can we offer an education with the sense of continuity and continuation of studies, starting, inexorably, with the various gestures, sounds, lips, bodies and identities that signal the teacher-student relations in the process of literacy.

\section{Final Considerations}

From the exposed, we reaffirm our understanding that these discussions should be considered when investigating or analyzing educational policies in Brazil, especially in the academic environment, in particular in the researches related to the public policies for the education of the young and adults.

These policies are markedly influenced by the determinations of international organizations, e.g. UNESCO, which, as mentioned, consolidated the qualifying function of education (professional qualification) and increased the insertion of competences turned to the world of work, necessary in the various economic sectors, from its orientations, especially in the two reports here analyzed. These marks contributed to and its grounds continue to influence worldwide to drive agendas and educational policies that incorporated the qualifying function of work in education.

The recommendations of this organization were also responsible for the diffusion of the perspective of lifelong education, which is favorable to the requirements of the job market and of the social role that is meant for, in this sense, each individual, different from the qualifying function of EJA and work as a humanizing source of wealth and social welfare.

Where it comes to EJA, the recommendations of UNESCO starting from the Mark of Belém emphasized the importance of literacy by considering it an inherent aspect of the right for education, calling attention to the challenges of literacy, in which we include those from EJA and especially for the eradication of illiteracy of the young and adults in the Brazilian territory.

We understand that in order to have a qualitative improvement of EJA, there must be the qualitative improvement of the initial and continued teacher formation, as well as improvement in the conditions of work and professionalization. This is an urgent compromise to be assumed by governments in relation to EJA, besides the formalization of its own system for this modality of basic education that attends to its specificities, the socially necessary demands and the interests of the young and adult population.

In this sense, we conclude this article calling to attention the importance of the pedagogical political project of the education of young people and adults and the formation of its teachers, the axis of which is, necessarily, the work-education relation, understanding the dual function of the school of socializing the historically accumulated culture and contributing to the transformation of the installed social relations. The worker-work relation is socially determined and EJA cannot ignore this reality; the awareness of the mechanisms of exploration will elucidate and enable for the human emancipation of the worker. 


\section{References}

Afonso, A. J. (2001). A redefinição do papel do estado e as políticas educativas: elementos para pensar a transição. Sociologia, Problemas e Práticas, Oeiras, (37). Retrieved from http:/www.scielo.mec.pt/scielo.php?script=sci_arttext\&pid=S087300003\&lng=pt\&nrm=iso

Afonso, A. J. (2001a). Reforma do estado e políticas educacionais: entre a crise do Estado-nação e a emergência da regulação supranacional. Educação \& Sociedade, 22(75), 15-32.

Atchoarena, D. (UNESCO) \& Gasperini, L. (FAO) (coords.). (2003). Education for rural development: towards new policy responses. Roma, Itália; Paris, França: UNESCO/FAO.

Baudelot, C., \& Establet, R. (1979). L’École primaire divise: um dossier. Paris, Maspero.

Baudelot, C., \& Establet, R. (1976). L'École capitaliste em France. Paris, Maspero.

Bezerra, A. A. C. (2007). Gestão democrática da construção de uma proposta curricular no ensino público: a experiência de Aracaju. Maceió: EDUFAL.

Bezerra, A. A. C. (2006). Apontamentos em educação: da natureza do trabalho pedagógico às políticas públicas em educação. Guarapari, ES: Ex Libris.

Bourdieu, P., \& Passeron, J. C. (1975). A reprodução: elementos para uma teoria do sistema de ensino. Rio de Janeiro: Francisco Alves.

Brasil. Lei $n^{\circ}$ 9.394, de 20 de dezembro de 1996. (1996). Establishes the guidelines and bases for the national education. Diário Oficial da União, Brasília, DF. Seção 1, p. 27833.

CAPES. OBEDUC/INEP/UNIT/PPED/GPGFOP. (2012). Transdisciplinaridade na literacia e numeracia de jovens e adultos do semiárido sergipano (TRANSEJA 2). Aracaju, Se. Edital 049/2012). (Project 2013 2017).

CAPES. OBEDUC/INEP/UNIT/PPED/GPGFOP. (2010). A transdisciplinaridade como alternativa teórico-metodológica para a efetividade da alfabetização e letramento de jovens e adultos no semiárido sergipano (TRANSEJA 1). Aracaju, Se. Edital 038/2010 (Project, 2011-2012).

Conselho Nacional de Educação (Brasil). (2000, 19 de Julho). Resolution CNE/CEB nº 1 de 2000. Diário Oficial da União, Brasília. Seção 1, p. 18.

Conselho Nacional de Educação (Brasil). (2000, 09 de junho). Judgment CNE/CEB nº 11/2000. Diário Oficial da União, Brasília. Seção 1e, p. 15.

Cordão, F. A. (2005). A educação profissional no Brasil. In: L.Pardal \& A. Ventura \& C. Dias. (2005) Ensino Médio e Ensino Técnico no Brasil e em Portugal: raízes históricas e panorama atual. Campinas: Autores Associados.

Gramsci, A. (1991a). Os intelectuais e a organização da cultura. Trad. Carlos Nelson Coutinho (4th ed.). Rio de Janeiro, RJ: Civilização Brasileira.

Gramsci, A. (1991b). Concepção dialética da história (9th ed.) Trad. Carlos Nelson Coutinho. Rio de Janeiro, RJ: Civilização Brasileira.

Lautier, B., \& Tortajada, R. (1978). École, force de travail et salarial. Paris, P.U.: Grenoble - Maspero.

Machado, L. R. de S. (1994). Politecnia, escola unitária e trabalho. São Paulo: Cortez.

Machado, L. R. de S. (1991). Politecnia no ensino de $2^{\circ}$ grau. In: SENEB. Politecnia no ensino médio. São Paulo: Cortez/SENEB/MEC.

Machado, M. A. de C. (2015). Políticas educacionais no Brasil na área de educação de jovens e adultos: o caso do Programa Brasil Alfabetizado em Sergipe. (Master Thesis). Aracaju, Se: UNIT.

MACHADO, L. R. de S. (1994). A educação e os desafios das novas tecnologias. In: FERRETI, C. J. et al (org.). Tecnologias, trabalho e educação: um debate multidisciplinar (p. 169-188). Petrópolis, RJ: Vozes.

Marx, K. (1982). O capital: crítica da economia política. (Livro 1, v. 1, 7th. ed.,1994). São Paulo: DIFEL.

Marx, K. (1975). Capítulo inédito d'o capital: resultados de produção imediato. (Biblioteca Ciência e Sociedade, (12), 1975). Translated by M. Antonio Ribeiro. Porto: Publicações Escorpião.

Marx, K. (1973). Educação popular e educação de adultos. São Paulo: Loyola. 
Paiva, V. (1994). Anos 90: as novas tarefas da educação dos adultos na América Latina. In INEP. Anais do encontro latino-americano sobre educação de jovens e adultos trabalhadores. Brasília.

Saviani, D. (2008a). História das ideias pedagógicas no Brasil. (2th ed. rev. e ampl.) Campinas: Autores Associados.

Saviani, D. (2008b). A nova lei da educação: trajetória, limites e perspectivas (11th ed.). Campinas: Autores Associados. (Contemporary Education Colection).

Saviani, D. (1996). Educação: do senso comum à consciência filosófica. Campinas (SP): Autores Associados.

Saviani, D. (1995). Escola e democracia. Campinas (SP): Autores Associados.

Saviani, D. (1987). Sobre a concepção de politecnia. Rio de Janeiro: FIOCRUZ. Politécnico da Saúde Joaquim Venâncio (Work presented during the "Seminário Choque Teórico").

UNESCO. (2010a). Relatório global sobre aprendizagem e educação de adultos. Brasília: UNESCO.

UNESCO. (2010b). Marco de ação de Belém. V Conferência Internacional sobre a Educação de Adultos. Brasília: UNESCO.

UNESCO. (1999). Declaração Hamburgo: agenda para o futuro. Conferência internacional de sobre a educação de adultos. (V; 1997: Hamburgo, Alemanha). Brasília: SESI/UNESCO.

UNESCO. (1998). Educação: um tesouro a descobrir. Translated by José Carlos Eufrázio. São Paulo: Cortez.

UNESCO. (1973). Aprender a ser: la educación del futuro (3th ed.). Madrid: Alianza Editorial. Retrieved from http://unesdoc.unesco.org/images/0013/001329/132984s.pdf

\section{Notes}

Note 1. Although not opposed to it, the qualifying function is not the same as professional qualification (technical level), as is posed in the Judgment number 16/99. This does not remove the complementary character of the function, given that it might happen at any moment inside or outside school life. This is why the basic level of professional education can be an expression of the qualifying function as much as learning aiming for a profession reconversion (CEB11.doc/SAO 006, p. 11).

Note 2. Education has solid grounds not only in economics and sociology but also in the evidence grounded in the psychological investigation that Man is an unfinished being that only fulfills itself with constant learning. Therefore, education has a place in all the ages of life, the multiplicity of situations and circumstances of existe. It recovers its true nature which is that of being permanent and global and gives limits to the institutions, programs and methods that are imposed throughout the centuries. (Our translation)

Note 3. This tendency, which was crated in the middle of the XX century, updates the ideas of the philosopher Thomas Malthus. It defended the idea that in underdeveloped countries the growing population would lead to the scarcity of natural resources and the increase of poverty and unemployment. Political policies were proposed, targeting birth control as a form of avoiding the situation, and various organizations, e.g. the World Bank and the IMF, started to require them in their business relations.

Note 4 . [...] one of the keys for access to the $21^{\text {st }}$ century. It overcomes the traditional distinction between initial education and permanent education, giving an answer to the challenged unleashed by a world in rapid transformation; such realization, however, does not constitute a new information, since precedent reports on education underlined the need for a return to school to deal with the new situations that occur in both private and professional lives. (UNESCO, p. 12-13. 2010c). (Our translation)

Note 5. [...] imposed by the opening of economic and financial frontiers, impelled by theories of free trade, reinforced by the dismemberment of the soviet block, instrumentalized by the new technologies of information the planetary interdependence does not cease to increase, in the economic, scientific, cultural and political spheres (UNESCO, 1998, p. 35). (Our translation)

Note 6. [...] the implementation of a basic school of universal character, of good quality and accessible by everyone, whatever their geographical, material, social or cultural situation is. It offers to all the possibility of having new opportunities, once the initial cycle of education has been finished. It also stimulates diverse talents, through the creation of multiple careers and should mobilize, for this effect, the group or resources accumulated by society. (UNESCO, 1998, p. 193). (Our translation) 
Note 7. The commission is favorable, then, to an ample decentralization of the educational systems, supported by the autonomy of schools and the effective participation of local agents. It is thought that this tendency is reinforced by the need for an education that extends itself throughout life, as well as the emergence of educational societies turned to the resources of informal education (UNESCO, 1998, p. 173). (Our translation)

Note $8 .[\ldots]$ it is reinforced by the need for an education that extends itself throughout life, as well as the emergence of educational societies turned to the resources of informal education. It is, however, conscious that the forms of management and education are not ends in themselves, but instrument whose value and efficacy depend greatly on the cultural, social, ec onomic and political contexts. The measures of decentralization can be carried out through both democratic processes and arbitrary processes that generate social exclusions. (UNESCO, 1998, p. 1973). (Our translation)

Note 9. [...] lifelong learning constitutes "a philosophy, a conceptual mark and an organizing principle of all forms of education, based in inclusive, democratic, humanistic and emancipatory values, being embracing and part of the vision of a society of knowledge". It highlighted its comprehension of the inter-sectorial and integrated nature of education and learning of young people and adults, the relevance of the formal, non-formal and informal processes, and their fundamental contribution to the sustainable future of the planet. (UNESCO, 2010b, p. 4). (Our translation)

Note 10. [..] the education of adults engulfs all processes of learning, informal or formal, in which people considered adult by society develop their capacities, enrich their knowledge and enhance their technical and professional qualifications, or redirect them to attend to their needs and those of their society (UNESCO, 2010b, p.5). (Our translation)

Note 11. [...] relevant contents and ways of implementation, evaluation of needs centered in the student, acquisition of multiple competences and knowledge, professionalization of educators, enrichment of learning environments and empowerment of individuals and communities (UNESCO, 2010b, p.9). (Our translation)

Note 12. Without a doubt, both in the present and the future, school, or actually, any organization conceived for methodic teaching, is, to the generation that starts its life, the decisive factor for the formation of a man apt for life, validly prepared for work (UNESCO, 1972, p. 39). (Our translation)

Note 13. This tridimensional action could not be conceived without the financial and technical support from the public sphere and the economic sector (industrial and agricultural). But a great part of the efforts to be made in this domain correspond to the initiative of groups, associations and individuals. This function of the private initiative constitutes an assurance of the respect towards freedoms and pluralities and favors pedagogical innovation (UNESCO, 1972, p. 291). (Our translation)

Note 14. [...] acquires, then, the dimension of a strategic investment that implicates on the mobilization of various types of actors: beyond the educational systems, private trainers, employers and worker representatives are summoned in a special manner. It is observed, thus, that in many industrialized countries there is a sensible increase on the financial means dedicated to permanent formation. Everything leads to the thought that this tendency will raise due to the evolution of work in modern societies. [...] It is no longer possible to ask educational systems to form labor for stable industrial jobs. It is, before that, about forming for innovation people capable of evolving, adapting to a world in rapid transformation and capable of mastering these transformations. (UNESCO, 1998, p. 71-72). (Our translation)

Note 15. Learning to make, as a means to acquire, not only a professional qualification, but, in a more ample way, competences that make the person apt to deal with numerous situations and to work in a team. But also learning to make in the scope of the diverse social experiences or of work that offer the young and teenagers, be it spontaneously, as a result of national or local context, be it formally, thanks to the developing of teaching alternated with work. (UNESCO, p. 101-102). (Our translation)

Note 16. [...] is dressed up in many forms: basic formation in a non-formal educational structure, part-time enrollment in universities, language courses, professional formation and recycling, formation from different associations or unions, systems of open learning and distance learning (UNESCO, 1998, p. 108). (Our Translation)

Note 17. Takes as an example the case of West Germany where there are clues of the emergence of two societies, one marked by a productive nucleus - salaried population which is framed in traditional sociological categories and another marked by an amplified population - which belongs to a growing periphery of unqualified, sustained poor people without any work regulation. Which are defined as evidences that point to a "crisis of the society of work". 
Note 18. Once work is understood in its more ample meaning, work as a production of human existence itself; work as a possibility of transforming the social and natural reality; work as a fundamental dimension of human life; work as culture, as reflective activity; work as a foundation of the process of creating knowledge; work as contradiction, since it is a reality in which are presented at least two great contradictions: between Man and Nature and between men, especially by the fact that we live in a society in which various forms of human subordination are processed in the reality of work. Finally, this more ample notion of the meaning of work is what concerns us in a reality such as ours, full of contradictions. (MACHADO, 1991, p. 53-54). (Our translation)

Note 19. The process of work is converted in the instrument of the process of adding value, of the process of self-valuation of capital: the creation of added value. The process of work is subsumed to the capital (it's the process of capital itself), and the capitalist comes in as the manager, guide; for this it is, at the same time, in a direct manner, a process of exploration of the work of others. This is what I denominate formal subsumption of work in capital. (MARX, 1975, p. 73). (Our translation)

Note 20. In the basis of the human potential of expression there has always been the power to qualify and requalify himself, and to find new fields of agency as a realization of himself. An opportunity can be the opening for the emergence of an artist, an intellectual, or for the discovery of a new personal aptitude. The completion of a person is not a closed and finished universe. The qualifying function, when activated, can be the road for these discoveries (BRASIL, 2000, p. 11). (Our translation)

\section{Copyrights}

Copyright for this article is retained by the author(s), with first publication rights granted to the journal.

This is an open-access article distributed under the terms and conditions of the Creative Commons Attribution license (http://creativecommons.org/licenses/by/4.0/). 